\title{
THE INFLUENCE OF THE PRINCIPAL'S MANAGERIAL ABILITY, TRAINING AND SPIRITUAL INTELLIGENCE ON TEACHER PERFORMANCE AT SMPN 1 RANTEPAO
}

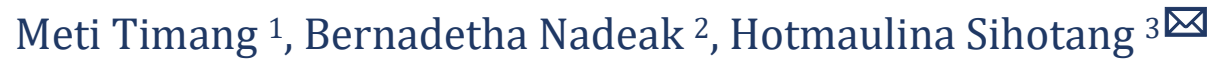 \\ 1,2,3 Magister of Education Management Department, Postgraduate Program, Universitas Kristen \\ Indonesia, Jakarta
}

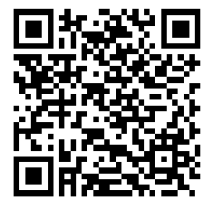

DOI: https://doi.org/10.29121/granthaalayah.v9.i2.2021.3526

Article Type: Research Article

Article Citation: Meti Timang,

Bernadetha Nadeak, and

Hotmaulina Sihotang. (2021). THE

INFLUENCE OF THE PRINCIPAL'S

MANAGERIAL ABILITY, TRAINING

AND SPIRITUAL INTELLIGENCE ON

TEACHER PERFORMANCE AT SMPN

1 RANTEPAO. International Journal of Research -GRANTHAALAYAH, 9(2), 248-256.

https://doi.org/10.29121/granthaa

layah.v9.i2.2021.3526

Received Date: 31 January 2021

Accepted Date: 28 February 2021

Keywords:

Managerial Ability

Spiritual Intelligence

Teacher Training

Performance

\begin{abstract}
The purpose of this study was to find out the influence of the headmaster's managerial ability on teacher performance, the influence of Teacher Spiritual Intelligence on Teacher performance, the influence of Teacher Training on student achievement, the influence of the principal's managerial ability, teacher training and spiritual intelligence on teacher performance at SMP Negeri 1 Rantepao. The method used in this research is a research method that is more towards the objective measurement aspect of social phenomena. The results showed that referring to the results of double linear regression analysis, and it can be concluded that managerial ability, training and spiritual intelligence have a significant and positive effect on teacher performance at SMP Negeri 1 Rantepao, meaning that if managerial ability, training and spiritual intelligence improve then the performance of teachers at SMP Negeri 1 Rantepao increased.
\end{abstract}

\section{INTRODUCTION}

Education is a very strategic vehicle in improving the quality of human resources which is a determinant of development. The implementation of education is an essential aspect to create quality human resources [1]. In-Law No.20 of 2003 on the national education system, article 4 contains "the purpose of national education aims to develop the potential of learners to become human beings who believe and believe in God almighty, noble, healthy, knowledgeable, capable, creative, independent and become citizens who are democratic and responsible in order to educate the life of the nation" [2], [3]. In the National Education System Law chapter II Article 4 which states: "National Education aims to develop the potential of learners to become human beings who believe, and believe in God almighty, noble, healthy, knowledgeable, capable, creative, independent and become democratic citizens and responsible in order to educate the life of the nation". 
The goal indicates that the establishment of quality human resources is a priority in Indonesian education. The large role of education in developing quality human resources in the concept order has not been fully realised. One of the crucial problems in the implementation of the education system today is improving the quality of education [4], [5]. School is an educational institution that must be appropriately managed to achieve the goals that have been set. The management requires the cooperation of all personnel in the school. The personnel directly involved in the school's education process are the principal, teachers, and school superintendents.

"Efforts to realise the objectives of national education to date are still experiencing many obstacles, among others, derived from the human resources of education providers, both in quality and quantity including equitable distribution of educational personnel, limited facilities and infrastructure or limited socioeconomic capabilities of the state and society as well as ever-changing education policies" [6]. As well as the constraints that are sourced from the education actors themselves, the quality of education can not be separated from the support of staffing personnel to support the administrative process."

So many factors influence teacher performance, and they are internal and external. Internally the teacher concerns spirituality and externally concerns the way the headmaster manages the school's processes and the teachers' ability to be processed from the training [7]. "Teachers as the spearhead of education and teaching providers are the closest people to the students. Teachers' function and role in Teaching and Learning Activities (KBM) have a strategic meaning in achieving educational objectives. Therefore, teachers must be able to show work achievements and be able to carry out the tasks given by the manager (principal). Especially in carrying out the teacher's professional duties, namely educating, teaching, and training students so that they achieve satisfactory learning achievements" [8], [9]. "The headmaster is successful in understanding the existence of the school as a complex and unique organisation, and can carry out the role of the headmaster as someone who is given the responsibility to lead the school" [10]. Thus, the headmaster as the leader is very important in carrying out the management function to achieve the school organisation's objectives.

It shows that the great expectations crush the role of the leader in the school or the headmaster's leadership in running the organisation's wheels as the person in charge of the organisation can integrate various activities and achieve the goals that have been set. Recognising the importance of a leader in a school held by a principal who is expected to play a significant role in achieving educational goals in schools is often the most responsible reason for the success or achievement of schools' educational goals [11], [12]. The balance between what is expected of a principal to the school's management and the contribution of the headmaster's ability to achieve the school's objectives does not always go according to reality.

Spiritual intelligence is the intelligence to confront and solve the problem of meaning or value, namely intelligence to place our behaviour and life in the context of a broader and richer meaning, intelligence to judge that one's actions or way of life are more meaningful than others [13]. Spiritual intelligence is the intelligence of the soul that can help a person build himself whole. Spiritual intelligence does not depend on culture or values. It does not follow existing values, but creates the possibility to have its values."

"A debate between IQ and EQ causes the emergence of spiritual intelligence. Therefore the term arises because IQ and EQ are seen as contributing only a portion of the determinant of one's success in life. Other factors play a role, namely spiritual intelligence, that emphasises more on the meaning of life and not just limited to the emphasis of religion alone" [14]. In order for potential skills and work skills, specifically for teachers, training is needed. In the educational environment (school) there are rides to build the ability and gain the latest knowledge, the rides are known as the deliberations of subject teachers (MGMP) and teachers working groups (KKG). In addition to $M G M P$ and $K K G$, training activities are sometimes carried out outside the school, usually organised by ( $L P M P)$, the Education Office, the Ministry of Education and other relevant agencies. Such forms of training are sometimes through workshops, seminars, administration, meetings and workshops. MGMP or $K K G$ is a vehicle or forum for professional activities of teachers of similar subjects or clumps of subjects conducted in the workshop and aims to discuss various issues related to quality improvement efforts, especially in the teaching and learning process. Training activities are essential and useful in improving skills, knowledge, attitudes and skills.

Performance is defined as an achievement, achievements shown, work skills shown and activities that teachers can do in teaching. Formal performance can be seen through a work achievement assessment [15], [16]. The assessment of work achievement has the use to develop an organisation that is efficient and effective because with the assessment of work achievement can be obtained input that the organisation or school has the extent to reach the objectives of the organisation following the previous set, to formulate and take new policies and that are more 
The Influence of the Principal's Managerial Ability, Training and Spiritual Intelligence on Teacher Performance at SMPN 1 Rantepao

adapted to the ability to achieve them. The success of teachers in organising education, among others, can be seen from the learning achievements of their students.

\section{THEORETICAL REVIEW}

According to Law of the Republic of Indonesia No. 14 of 2005 concerning Teachers and Lecturers: "teachers are professional educators with the main task of educating, teaching, guiding, directing, training, assessing and evaluating learners in early childhood education, primary education, and secondary education" [17]. Therefore, performance improvement needs to be done so that teachers can carry out their primary tasks properly. performance is a translation of the word "performance". Etymologically performance comes from the word "to perform" which means to display or perform. "Performance is output derives from processes, human or otherwise, i.e. performance is the result of a process performed by man" [18].

A teacher's task is burdensome and complete so that in order for the teacher to work correctly, it needs to be analysed about the factors that influence and what policies need to be taken so that the teacher's performance can increase. "Teacher performance is influenced by intrinsic factors of teachers (personal/individual) or HR and extrinsic factors, namely leadership, system, team, and situational" [19]. The ability is a thing that has been in us since birth. The ability that exists in human beings can also be called potential. The potential that exists in humans can basically be honed. In the Indonesian dictionary, ability comes from the word capable, which means power (can, can, do something, can have excessive wealth), in the great dictionary of Bahasa Indonesia. Ability is defined as ability or proficiency so that it can be said that ability is an ability to do something.

Every employee, in general, is hoping for better skills through further education, but it will not come by itself if the employee in question does not attempt to develop his/her skills and knowledge through education, both formal education and non-formal education [20]. With increasing ability and knowledge, it is expected that employees can also improve the quality of their work. Managerial is related to the management of the organisation by managers. Therefore, the managerial ability is related to the ability of managers in leading the organisation. Managerial competence can be interpreted as the ability to manage resources through planning, organising, directing, and supervision activities to achieve organisational objectives effectively and efficiently [21], [22]. The headmaster, as the manager, must be able to perform the functions of education management well. The headmaster's managerial problems are related to the limited resources, both physical and non-physical, making it difficult for the headmaster to perform good school governance. At the same time, institutional problems are related to internal problems that arise, both after the possession of resources and the limitations of resources. These problems if left will be difficult to make the school better. Therefore, the headmaster must respond by managing the education personnel properly [23].

Training means the process, the way, the act of training; activities or coaching work. Training is a series of individual activities in systematically improving skills and knowledge to be able to have professional performance in their fields [24], [25]. Training is a learning process that allows employees to carry out the work that is now following the standards. Training is the process of systematically changing employee behaviour to achieve organisational goals. Training is related to the skills and ability of employees to carry out the current work.

Training is used to address low teacher skills. Training programs must be provided based on need. The type of training that is programmed must match what types of abilities are still low. The training will take place optimally if designed according to the needs, methods and the right time [26], [27]. The word spiritual comes from the Latin word "spirit" which means 'spritus" which means breath, from English it is called "spirit" which means pure, and spirit. Spirit, in general means the power of power that animates and moves. In modern terms, it refers to the energy of life, commonly called 'non-physical' which includes emotions and characters. According to Vitale, "Spirit is that which is traditionally believed to be the vital principle for animating force within living beings". It means that the soul is a hereditary belief that is an important beginning to bring to life the power of life.

From the spiritual world comes the word spirituality. The understanding of many people that spirituality is only related to spirituality or things that show the righteous's various activities to obtain holiness and salvation in the hereafter [28]. Based on the word "spirit", spirituality can be interpreted as a force that gives a person or group endurance in maintaining and developing their life. Thus, it appears that spirituality generally refers to spiritual matters (problems of the afterlife) and human life in all fields, both social, economic, and political culture and others. Spirituality is man's consciousness and attitude in striving to maintain his life to achieve reasonable life goals. 


\section{RESEARCH METHOD}

The method used is the quantitative method where Quantitative Research is a research method that is more towards the aspect of objective measurement of social phenomena. Quantitative research is a type of systematic, structured type, composed steadily from the beginning to the end of the research, and tends to use statistical figures analysis. The type of research carried out is verification with the explanatory approach. Verification research with explanatory is a research that is in the form of testing the results of rational thinking whose truth is temporary (hypothesis) that analyses a status of a human group, an object, a condition, or an event in the present by knowing the problem and obtaining justification for significant influence.

\section{RESEARCH AND DISCUSSION RESULTS}

To test the instrument used, it is necessary to test the validity and reliability in validity testing, and the result shows that the instrument is said to be valid if $r$ calculates more than $r$ table in this test for the amount of data as much as 20 then obtained $r$ table of 0.444 .

Table 1: Managerial Capability Validity Test Results

\begin{tabular}{|c|c|}
\hline & Correlations \\
\hline & X1_ITEM_TOTAL \\
\hline X1_ITEM_1 & $.813^{*}$ \\
\hline X1_ITEM_2 & $.806^{\prime \prime}$ \\
\hline X1_ITEM_3 & $.806^{*}$ \\
\hline X1_ITEM_4 & $.759^{\prime \prime}$ \\
\hline X1_ITEM_5 & $.711^{\prime \prime}$ \\
\hline X1_ITEM_6 & $.711^{\prime \prime}$ \\
\hline X1_ITEM_7 & $.547^{\circ}$ \\
\hline X1_ITEM_8 & $.447^{\circ}$ \\
\hline X1_ITEM_9 & $.658^{\prime \prime}$ \\
\hline X1_ITEM_10 & $.869^{\prime \prime}$ \\
\hline X1_ITEM_11 & $.711^{\prime \prime}$ \\
\hline
\end{tabular}

\begin{tabular}{|c|c|}
\hline \multicolumn{2}{|c|}{ Correlations } \\
\hline & X1_ITEM_TOTAL \\
\hline X1_ITEM_12 & $.632^{\prime \prime}$ \\
\hline X1_ITEM_13 & $.602 "$ \\
\hline X1_ITEM_14 & $.777^{* \prime}$ \\
\hline X1_ITEM_15 & $.744 "$ \\
\hline X1_ITEM_16 & $.638^{\prime \prime}$ \\
\hline X1_ITEM_17 & .782 \\
\hline X1_ITEM_18 & .635 \\
\hline X1_ITEM_19 & $.449^{\circ}$ \\
\hline X1_ITEM_20 & $.713^{\prime \prime}$ \\
\hline X1_ITEM_21 & $.734^{* \prime}$ \\
\hline X1_ITEM_22 & $.762 "$ \\
\hline
\end{tabular}

Table 2: Training Validity Test Results

\begin{tabular}{|l|r|}
\hline \multicolumn{2}{c}{ Correlations } \\
\hline X2_ITEM_1 & X2_ITEM_TOTAL \\
\hline X2_ITEM_2 & $.513^{\circ}$ \\
\hline X2_ITEM_3 & $.507^{\circ}$ \\
\hline X2_ITEM_4 & $.456^{\circ}$ \\
\hline X2_ITEM_5 & $.601^{*}$ \\
\hline X2_ITEM_6 & $.519^{\circ}$ \\
\hline X2_ITEM_7 & $.780^{\circ}$ \\
\hline X2_ITEM_8 & $.816^{\circ}$ \\
\hline
\end{tabular}

\begin{tabular}{|l|r|}
\hline & Correlations \\
\hline X2_ITEM_9 & $.761^{\prime \prime}$ \\
\hline X2_ITEM_10 & $.678^{*}$ \\
\hline X2_ITEM_11 & $.816^{*}$ \\
\hline X2_ITEM_12 & $.767^{*}$ \\
\hline X2_ITEM_13 & $.791^{*}$ \\
\hline X2_ITEM_14 & $.738^{* \prime}$ \\
\hline X2_ITEM_15 & $.878^{*}$ \\
\hline
\end{tabular}

Table 3: Spiritual Intelligence Validity Test Results

\begin{tabular}{|l|r|}
\hline \multicolumn{2}{|c}{ Correlations } \\
\hline X3_ITEM_1 & X3_ITEM_TOTAL \\
\hline X3_ITEM_2 & $.615^{\prime \prime}$ \\
\hline X3_ITEM_3 & $.597^{*}$ \\
\hline X3_ITEM_4 & $.460^{\circ}$ \\
\hline X3_ITEM_5 & $.659^{\prime \prime}$ \\
\hline X3_ITEM_6 & $.854^{*}$ \\
\hline X3_ITEM_7 & $.643^{*}$ \\
\hline X3_ITEM_8 & $.758^{\prime \prime}$ \\
\hline X3_ITEM_9 & $.720^{*}$ \\
\hline X3_ITEM_10 & $.455^{\circ}$ \\
\hline
\end{tabular}


The Influence of the Principal's Managerial Ability, Training and Spiritual Intelligence on Teacher Performance at SMPN 1 Rantepao

Table 4: Performance Validity Test

Correlations
\begin{tabular}{|l|r|}
\hline \multicolumn{1}{|c|}{} & Y_ITEM_TOTAL \\
\hline Y_ITEM_1 & $.836^{*}$ \\
\hline Y_ITEM_2 & $.512^{\circ}$ \\
\hline Y_ITEM_3 & $.894^{*}$ \\
\hline Y_ITEM_4 & $.834^{*}$ \\
\hline Y_ITEM_5 & $.732^{*}$ \\
\hline Y_ITEM_6 & $.494^{\circ}$ \\
\hline Y_ITEM_7 & $.826^{\circ}$ \\
\hline Y_ITEM_8 & $.738^{*}$ \\
\hline
\end{tabular}

Correlations
\begin{tabular}{|l|r|}
\hline \multicolumn{1}{|c|}{} & Y_ITEM_TOTAL \\
\hline Y_ITEM_9 & $.763^{*}$ \\
\hline Y_ITEM_10 & $.885^{*}$ \\
\hline Y_ITEM_11 & $.743^{*}$ \\
\hline Y_ITEM_12 & $.885^{\circ}$ \\
\hline Y_ITEM_13 & $.840^{*}$ \\
\hline Y_ITEM_14 & $.649^{*}$ \\
\hline Y_ITEM_15 & $.656^{*}$ \\
\hline Y_ITEM_16 & $.496^{\circ}$ \\
\hline
\end{tabular}

Based on the test results above, each item variable's correlation value is more than 0.444 , and then it can be concluded that all items in the variable are valid.

Table 5: Reliability Test Results

\begin{tabular}{|c|c|c|}
\hline Variable & Sig & Note \\
\hline Managerial Ability & 0,945 & Reliable \\
\hline Training & 0,911 & Reliable \\
\hline Spiritual Intelligence & 0,844 & Reliable \\
\hline Performance & 0,924 & Reliable \\
\hline
\end{tabular}

Based on the test using SPSS program above, Cronbach's Alpha value obtained more than 0.444 then it can be concluded that the instrument item variable reliabel performance

Table 6: Test Normality

\begin{tabular}{|c|c|c|}
\hline Variable & Sig & Note \\
\hline Managerial Ability & 0,200 & Normal \\
\hline Training & 0,200 & Normal \\
\hline Spiritual Intelligence & 0,200 & Normal \\
\hline Performance & 0,200 & Normal \\
\hline
\end{tabular}

Based on normality test results for performance variables above, it appears that the significance value of Kolmogorov-Smirnov $>0.05$ so that it can be concluded that the data on all variables in this study are typically distributed

Table 7: Linearity Test

\begin{tabular}{|c|c|c|}
\hline Variable & Sig & Note \\
\hline Managerial Ability & 0,000 & Linear \\
\hline Training & 0,000 & Linear \\
\hline Spiritual Intelligence & 0,000 & Linear \\
\hline
\end{tabular}

Based on the test results above, it appears that the linearity significance value is less than 0.0 so it can be concluded that the relationship of free variables with performance is linear. 
Table 8: Correlation Analysis

\begin{tabular}{|c|c|c|c|c|c|}
\hline \multicolumn{6}{|c|}{ Correlations } \\
\hline & & $\begin{array}{l}\text { KEMAMPUAN_ } \\
\text { MANAJERIAL }\end{array}$ & PELATIHAN & $\begin{array}{c}\text { KECERDASAN_ } \\
\text { SPIRITUAL }\end{array}$ & KINERJA \\
\hline \multirow{4}{*}{$\begin{array}{l}\text { KEMAMPUAN_ } \\
\text { MANAJERIAL }\end{array}$} & Pearson Correlation & 1 & $.625^{\circ}$ & $.476^{\circ}$ & $690^{*}$ \\
\hline & Sig. (2-tailed) & & .000 & .000 & .000 \\
\hline & $\mathrm{N}$ & 60 & 60 & 60 & 60 \\
\hline & Pearson Correlation & $.625^{\circ}$ & 1 & $.506^{*}$ & $691^{*}$ \\
\hline \multirow[t]{2}{*}{ PELATIHAN } & Sig. (2-tailed) & .000 & & .000 & .000 \\
\hline & $\mathrm{N}$ & 60 & 60 & 60 & 60 \\
\hline \multirow{4}{*}{$\begin{array}{l}\text { KECERDASAN } \\
\text { _SPIRITUAL }\end{array}$} & Pearson Correlation & $.476^{\circ}$ & $.506^{*}$ & 1 & $.614^{*}$ \\
\hline & Sig. (2-tailed) & .000 & .000 & & .000 \\
\hline & $\mathrm{N}$ & 60 & 60 & 60 & 60 \\
\hline & Pearson Correlation & $.690^{*}$ & $.691^{*}$ & $.614^{-1}$ & 1 \\
\hline \multirow[t]{2}{*}{ KINERJA } & Sig. (2-tailed) & .000 & .000 & .000 & \\
\hline & $\mathrm{N}$ & 60 & 60 & 60 & 60 \\
\hline
\end{tabular}

The SPPS calculation above shows that: a) The coefficient of managerial ability correlation with training is 0.625 . It shows that the degree of density between managerial ability variables and training is positive and is in a strong category. Sig value. (2-tailed) of 0.00 , where it is less than 0.05 , shows that the correlation between the two variables is very significant; b) The coefficient of managerial ability correlation with spiritual intelligence is 0.476 . IT shows that the degree of density between managerial capability variables and spiritual intelligence is positive and moderate. Sig value. (2-tailed) of 0.00 , where less than 0.05 , shows that the correlation between the two variables is very significant; c) Coefficient of managerial ability correlation with the performance of 0.690 . It shows that the degree of density between managerial capability variables and performance is positive and is in a strong category. Sig value. (2-tailed) of 0.00 , where less than 0.05 it shows that the correlation between the two variables is very cynical; d) Correlation coefficient of training with spiritual intelligence of 0.506 . this shows that the degree of density between managerial and training capability variables is positive and moderate. Sig value. (2-tailed) of 0.00 , where less than 0.05 it shows that the correlation between the two variables is very cynical; e) The correlation coefficient of training with performance was 0.691 . It shows that the degree of density between managerial ability variables and training is positive and is in a strong category. Sig value. (2-tailed) of 0.00 , where less than 0.05 , shows that the correlation between the two variables is very cynical; dan $\mathrm{f}$ ) The correlation coefficient of spiritual intelligence with performance was 0.614 . It shows that the degree of density between managerial ability variables and training is positive and is in a strong category. Sig value. (2-tailed) of 0.00 where less than 0.05 it shows that the correlation between the two variables is very cynical.

Table 9: Determination Test Results

\begin{tabular}{l|r|r|r|c|}
\hline Model & R & R Square & $\begin{array}{c}\text { Adjusted R } \\
\text { Square }\end{array}$ & $\begin{array}{l}\text { Std. Error of the } \\
\text { Estimate }\end{array}$ \\
\hline 1 & $.801^{\mathrm{a}}$ & .642 & .623 & .28147 \\
\hline
\end{tabular}
a. Predictors: (Constant), KECERDASAN_SPIRITUAL,
KEMAMPUAN_MANAJERIAL, PELATIHAN

Based on the above processing results, the coefficient of determination of R Square of 0.642 or $64.2 \%$ was obtained. It indicates that the considerable influence of free variables (managerial ability, training and spiritual intelligence) on bound variables (performance) was $64.2 \%$ and the rest was influenced by other variables not included in this study. 
The Influence of the Principal's Managerial Ability, Training and Spiritual Intelligence on Teacher Performance at SMPN 1 Rantepao

Table 9: Test Result F

\begin{tabular}{|rl|r|r|r|r|r|}
\hline \multicolumn{1}{|l|}{ Model } & & Sum of Squares & \multicolumn{1}{c|}{ df } & Mean Square & F & Sig. \\
\hline \multirow{4}{*}{1} & Regression & 7.952 & 3 & 2.651 & 33.456 & $.000^{\mathrm{b}}$ \\
& Residual & 4.437 & 56 & .079 & & \\
& Total & 12.388 & 59 & & & \\
\hline
\end{tabular}

a. Dependent Variable: KINERJA

b. Predictors: (Constant), KECERDASAN_SPIRITUAL, KEMAMPUAN_MANAJERIAL,

PELATIHAN

Test result $\mathrm{F}$ shows a significance value (Sig.) of 0.000 . It means that free variables (X1, X2, X3) affect bound variables (Y).

Table 10: Test Result $\mathrm{t}$

\begin{tabular}{|c|c|c|c|c|c|c|}
\hline \multicolumn{7}{|c|}{ Coefficients ${ }^{\mathrm{a}}$} \\
\hline \multirow[t]{2}{*}{ Mod } & & \multicolumn{2}{|c|}{ Unstandardized Coefficients } & \multirow{2}{*}{$\begin{array}{c}\text { Standardized } \\
\text { Coefficients } \\
\text { Beta } \\
\end{array}$} & \multirow[t]{2}{*}{$t$} & \multirow[t]{2}{*}{ Sig. } \\
\hline & & B & Std. Error & & & \\
\hline \multirow{5}{*}{1} & (Constant) & .134 & .380 & & .353 & .725 \\
\hline & KEMAMPUAN_MANAJERIA & .357 & .107 & .350 & 3.323 & .002 \\
\hline & L & & & & & \\
\hline & PELATIHAN & .340 & 1111 & .330 & 3.070 & .003 \\
\hline & KECERDASAN_SPIRITUAL & 314 & 107 & .280 & 2.932 & .005 \\
\hline
\end{tabular}

Constant of 0.134 if the variable managerial ability (X1), training (X2) and spiritual intelligence (X3) is 0 , then the performance of teachers in SMP Negeri 1 Rantepao is 0.134 . The coefficient of managerial ability variable regression of 0.357 means that every increase or decrease in each unit's managerial ability will increase or decrease in the performance of SMP Negeri 1 Rantepao by 0.357 units assuming the variables of Training and Spiritual Intelligence are fixed in value. A positive value indicates that with the increasing variable managerial ability, then the performance is increasing. The regression coefficient of training variables of 0.340 means that every increase or decrease in each unit's training will increase or decrease in the performance of teachers of SMP Negeri 1 Rantepao by 0.340 units assuming the Managerial variable ability and spiritual intelligence of fixed value. Positive values indicate that the increasing training variables, the improved performance. The regression coefficient of spiritual intelligence variable of 0.314 means that every increase or decrease in spiritual intelligence per unit will increase or decrease in the performance of teachers of SMP Negeri 1 Rantepao by 0.314 units assuming the variable Managerial Ability and Training value remains. Positive values indicate that the increasing variables of spiritual intelligence, the more performance increases.

Based on the above results, it appears that the managerial capability variable has the largest regression coefficient of 0.357. It shows that the headmaster's managerial ability influences teachers' performance at $S M P$ Negeri 1 Rantepao. It means that: a) The value t calculates the managerial capability variable of 3,323 where it is more than 1,671. So that $\mathrm{H} 0$ is rejected, and $\mathrm{Ha}$ is accepted meaning that individually the variable managerial ability is based on the performance of teachers at SMP Negeri 1 Rantepao; b) The value t calculates the training variable of 3,070 where it is more than 1,671. So $\mathrm{H0}$ is rejected and Ha is accepted, meaning that individually the training variables affect teachers' performance at SMP Negeri 1 Rantepao; dan c) T value calculates managerial capability variable of 2,932 were more than 1,671. So H0 is rejected, and Ha is accepted, meaning that individually the variables of spiritual intelligence affect teachers' performance at SMP Negeri 1 Rantepao.

\section{CONCLUSIONS}

This study's conclusion is as follows: a) Value $\mathrm{R}$ or correlation value between managerial capability variable with the performance of 0.690 so that it is based on a strong category. R Square or a coefficient of determination value of 0.476 . It means that the percentage of managerial capability variable capability measure explaining the 
variation of performance variables is $47.6 \%$. Based on simple linear regression analysis, it appears that the relationship pattern of both variables is linear and positive meaning that if the managerial ability value increases, then the performance of teachers at SMP Negeri 1 Rantepao will increase; b) The correlation value between training variables and performance is 0.691 so that it is in a strong category. R Square or a coefficient of determination value of 0.478 . It means that the percentage of training variable capability size explaining the variation of performance variables is $47.8 \%$. Based on simple linear regression analysis, it appears that the relationship pattern of the two variables is linear and positive meaning that if the training value increases, then the performance of teachers at SMP Negeri 1 Rantepao will increase; c) Value $\mathrm{R}$ or correlation value between spiritual intelligence variable and performance of 0.614 . It also appears that the value of $\mathrm{R}$ Square or the coefficient of determination is 0.377 . It means that the percentage of the measure of spiritual intelligence variable capability explains the variation of performance variables is $37.7 \%$. Based on simple linear regression analysis, it appears that the relationship pattern of the two variables is linear and positive meaning that if the value of spiritual intelligence increases, then the performance of teachers at SMP Negeri 1 Rantepao will increase; dan d) R Square determination coefficient of 0.642 or $64.2 \%$. It indicates that the extensive influence of free variables (managerial ability, training and spiritual intelligence) on bound variables (performance) was $64.2 \%$ and the rest was influenced by other variables not included in this study. Referring to the results of double linear regression analysis, it can be concluded that managerial ability, training and spiritual intelligence have a significant and positive effect on teacher performance at SMP Negeri 1 Rantepao, meaning that if managerial ability, training and spiritual intelligence improve then the performance of teachers at SMP Negeri 1, Rantepao will increase.

\section{SOURCES OF FUNDING}

This research received no specific grant from any funding agency in the public, commercial, or not-for-profit sectors.

\section{CONFLICT OF INTEREST}

The author have declared that no competing interests exist.

\section{ACKNOWLEDGMENT}

None.

\section{REFERENCES}

[1] Hopkins, D. (2015). Improving the quality of education for all: A handbook of staff development activities. Routledge.

[2] Tyas, E. H., \& Naibaho, L. (2020). Building Superior Human Resources through Character Education. TEST Engineering \& Management, 83, 11864-11873.

[3] Schuck, S., Aubusson, P., Kearney, M., \& Burden, K. (2013). Mobilising teacher education: A study of a professional learning community. Teacher Development, 17(1), 1-18.

[4] Al-Adwan, A., \& Smedley, J. (2012). Implementing e-learning in the Jordanian Higher Education System: Factors affecting impact. International Journal of Education and Development using ICT, 8(1).

[5] Naibaho, L. (2014). The Role of Education and Culture in the Development of Character and Civilization of the Plural Indonesian Nation. Jurnal the Ary Suta Center Series on Strategic Management, 27(0), 69.

[6] Schneckenberg, D. (2009). Understanding the real barriers to technology-enhanced innovation in higher education. Educational Research, 51(4), 411-424.

[7] Day, C., \& Gu, Q. (2013). Resilient teachers, resilient schools: Building and sustaining quality in testing times. Routledge.

[8] Nadeak, B., \& Naibaho, L. (2020). The Effectiveness of Problem-Based Learning on Students' Critical Thinking. Jurnal Dinamika Pendidikan, 13(1), 1-7. 
The Influence of the Principal's Managerial Ability, Training and Spiritual Intelligence on Teacher Performance at SMPN 1 Rantepao

[9] Tyas, E. H., \& Naibaho, L. (2020). Building Superior Human Resources through Character Education. TEST Engineering \& Management, 83, 11864-11873.

[10] Roddy, T. (2010). Frame analysis of the self-perceived leadership orientations of headmasters of the independent schools association of the southwest, southern association of independent schools, and the association of independent schools of greater Washington member schools.

[11] McGuigan, L., \& Hoy, W. K. (2006). Principal leadership: Creating a culture of academic optimism to improve achievement for all students. Leadership and policy in schools, 5(3), 203-229.

[12] Sormin, E., Julianti, K., Nadeak, B., \& Naibaho, L. (2019). Use of construction inquiri learning model to improve the interest of learning students grade XI SMA Angkasa 2 in coloid materials. PEOPLE International Journal of Social Sciences, 5(2), 908-917.

[13] Karelitz, T. M., Jarvin, L., \& Sternberg, R. J. (2010). The meaning of wisdom and its development throughout life. The Handbook of Life-Span Development.

[14] Nharirire, E. (2018). An investigation into the relationship between spiritual intelligence, emotional intelligence, coping ability, and burnout among humanitarian aid workers in Zimbabwe (Doctoral dissertation).

[15] Nadeak, B., \& Naibaho, L. (2019). Managing Lecturers' Competence Development at Universitas Kristen Indonesia.

[16] Nadeak, B., Iriani, U. E., Naibaho, L., Sormin, E., \& Juwita, C. P. (2019). Building Employees' Mental Health: The Correlation between Transactional Leadership and Training Program with Employees' Work Motivation at XWJ Factory. Indian Journal of Public Health Research \& Development, 10(6), 1373-1379.

[17] Naibaho, L. (2019). The Effectiveness of Scaffolding Method on Students' Speaking Achievement. International Journal of Research-Granthaalayah, 7(5), 193-201.

[18] Nadeak, B., \& Naibaho, L. (2018). The Description of medical students' interest and achievement on anatomy at faculty of medicine Universitas Kristen Indonesia. International Journal of Sciences: Basic and Applied Research (IJSBAR), 39(1), 121-133.

[19] Thoonen, E. E. J. (2012). Improving classroom practices: the impact of leadership, school organizational conditions, and teacher factors. Universiteit van Amsterdam [Host].

[20] Nadeak, B., Naibaho, L., Sormin, E., \& Juwita, C. P. (2019). Healthy Work Culture Stimulate Performance. Indian Journal of Public Health Research \& Development, 10(6), 1385-1389.

[21] Ogbo, A. I., \& Ukpere, W. I. (2014). The impact of effective inventory control management on organisational performance: A study of 7up bottling company nile mile enugu, nigeria. Mediterranean Journal of Social Sciences, 5(10), 109-109.

[22] Nadeak, B., Simanjuntak, D. R., Naibaho, L., Sormin, E., Juwita, C. P., \& Pardede, S. O. (2019). Analysis of Nursing Quality Services. Indian Journal of Public Health Research \& Development, 10(6), 1380-1384.

[23] Nicholls, A. (2018). Managing educational innovations. Routledge.

[24] Obi-Anike, H. O., \& Ekwe, M. C. (2014). Impact of training and development on organizational effectiveness: Evidence from selected public sector organizations in Nigeria. European Journal of Business and Management, 6(29), 66-75.

[25] Aguinis, H., \& Kraiger, K. (2009). Benefits of training and development for individuals and teams, organizations, and society. Annual review of psychology, 60, 451-474.

[26] Nadeak, B. (2016). The Influence of Organizational Culture on the Organizational Citizenship Behavior (OCB) of Lecturers at the Christian University of Indonesia (UKI). Jurnal Manajemen Pendidikan, 5(1), 1-10.

[27] Sihotang, H., \& Nadeak, B. (2017). Leadership Based on the Internal Quality Assurance System in the Christian University of Indonesia. Advances in Social Science, Education and Humanities Research (ASSEHR), 66, 3543.

[28] Van der Kooi, C. (2018). This incredibly benevolent force: the Holy Spirit in reformed theology and spirituality. Wm. B. Eerdmans Publishing. 